stwa zastępują mi miłość cjczyzny; zresztą tych dóbr nikt nie potrafi mi wyrwać":

Zewnętrzny wygląd Kratesa był brzydki, w dodatku zniekształcał go wielki garb. Czystości nie uznawał, chodził stale brudny. Zimową porą nosił ubranie lekkie a latem ciepłe. Najczęściej jednak wkładał na siebie płaszcz zeszyty $\mathrm{z}$ niewyprawionych kozich skór, który filozofa z natury już brzydkiego jeszcze bardziej szpecil i czynił podobnym do prawdziwego potwora. Pomimo to jednak Krates był lubiany przez Ateńczyków dla swoich cnót obywatelskich i dla swej wielkiej łagodności; nawet bicie filozof znosił cierpliwie. Nie przeszkodziło to wszystko również, by Hiparchia, kobieta bardzo wykształcona, poślubiła go i obdarzyła dwoma córkami, które Krates oddał za żony dwom swoim uczniom.

Ks. A. PETRANI

\title{
Kłopoty dyrygenta w Jubileuszowym Roku Maryjnym
}

Kłopoty powiedzieć: urządzić koncert pieśni maryjnych. Ale repertuar?! Skąd go wziąć? W tym trudność. Bo że koncert taki każdy dyrygent chóru kościelnego dać powinien, to nie ulega wątpliwości. Pobudką do tego jest nie tylko Polski Rok Maryjny, ale przede wszystkim ważna encyklika papieża Piusa XII o muzyce kościelnej: „Musicae sacrae disciplina".

Od 50-ciu lat, kiedy Pius X przez „Motu Proprio“ zapowicdział wielką w dziejach Kościoła reformę muzyki kościelnej, skazując na wycięcie chwasty, które, zdawało się zyskaly sobie w kościele domicilium, żadna z następnych encyklik papieskich nie zrobiła takiego wrażenia w świecie muzycznym, jak ta z Bożego Narodzenia 1955 roku. Nigdy bowiem Najwyższy Zwierzchnik Kościoła nie zwrócił się do muzyków kościelnych $\mathrm{w}$ tak wielkich słowach, podnosząc rolę kompozytorów, dyrygentów, chórzystów, instrumentalistów aż tak wysoko, żeby zadanie ich i obowiązek godnie wykonany można było nazwać „prawdziwym i istotnym apostolstwem“, zapewniającym „od Chrystusa Pana nagrodę i chwałę apostołów".

Słowa poszly $\mathrm{w}$ świat. Trafiły i do nas. Pewnego dnia rozebrzmiały one $\mathrm{w}$ naszej sali muzyki. Wieloletni chórzyści, co $\mathrm{z}$ poświęceniem i wyrzeczeniem się niejednej godziwej rozrywki niestrudzenie uczęszczali na próby chóru, słysząc je, ani spostrzegli się, jak ręka siẹgnęla po chusteczkę, by ukryć łzy wzruszenia. Daje się potem słyszeć, że ów dzień, który objawił im słowa tak zachwycające a jednocześnie tak nieoczekiwane, był dniem najpiękniejszej lekcji śpiewu. Samorzutnie prosili, by od tego dnia nie rozpoczynano żadnej próby bez odmówienia Modlitivy Pańskiej i Ave. Cwiczenie repertuaru chórowego nabrało jakis- 
goś namászczenia, stało się czymś uroczystym. Czuliśmy, że na naszych próbach zapanowała odtąd atmosfera niezwykle podniosła. Zrodziła się w zespole świadomość, że słowa papieskie przekazują nam przedziwną władzę otwierania pieśnią serc ludzkich, w których mieliśmy obudzić tęsknotę za Najwyższym Pięknem.

To słowo „apostolstwo" nie dawało spokoju. Coraz częściej chórzyści uprzytamniali sobie tę myśl, że muzykom zostało powierzone $\mathrm{w}$ hierarchii funkcji kościelnych zadanie rzeczywiście doniosłe. Papież nazywał nas „pomocnikami Chrystusa Pana w apostolstwie“.

Ze wzrostem poczucia wielkiej misji, jaką mamy do spełnienia, przychodziło teraz do głosu to, co jest istotne w apostolstwie: owa święta niecierpliwość, by, zrozumiawszy troskę papieża, poświęcić swe siły przemianie rzeczywistości, wedle nakazów żarliwości apostolskiej.

Myśleliśmy tak: zwrócenie się tak serdeczne do wykonawców muzyki kościelnej - obowiązuje! Muszą być wypełnione postulaty, które papieżowi leżą na sercu. Czy wobec tego dyrygent, który w Polskim Roku Maryjnym nie urządzi koncertu pieśni maryjnej, będzie mógł sobie powiedzieć, że zrobił co do niego należało, że zrozumiaì ducha encykliki? Odpowiedź była jasna. Ale repertuar? Właśnie! Żyliśmy jeszcze wspomnieniem wielkich przeżyć estetycznych i religijnych, których byliśmy świadkami, dając koncerty pod tytulem: „Wędrówka pieśni przez misteria roku liturgicznego!“ Pisali nam później słuchacze: „Dlaczegośmy wcześniej nie przeżyli takich wzruszeń wewnętrznych, jak w dzień naszego koncertu? Koleje naszego życia potoczyłyby się calkiem inaczej".

"Wędrówka pieśni przez misteria roku liturgicznego" odtwarzała w treści i nastroju największy dramat dziejów ludzkich: tajemnicę życia i śmierci J. Chrystusa. Czy koncert w Polskim Roku Maryjnym będzie zdolny wydobyć równie głębokie akcenty estetyczne i religijne? A jednak, koncert musi być urządzony i to kilkakrotnie, w różnych kościołach. Co tu począć? Do sprawy tak wielkiej dla nas wagi należało: po pierwsze - nabrać zaufania do imprezy tego rodzaju: że mianowicie, samo wykonanie wybitnych pieśni i kantat maryjnych może dać silne przeżycie religijne. Po drugie: znaleźć odpowiedni do tego repertuar. I... mieliśmy szczęście.

O pierwszym przekonał mnie sprowadzony przez Bohdana Wodiczkę chór i orkiestra Radia Berlińskiego ze mszą J. Seb. Bacha i Mesjaszem Haendla. Szczęśliwym trafem zdarzyło się, że i mój zespół mógł niedługo potem wysłuchać transmisji z Filharmonii Narodowej, gdzie znów tenże sam nieoceniony Wodiczko olśnił wszystkich kapitalnym wykonaniem „Magnificat" J. Seb. Bacha.

Powoli zaczynały się teraz kształtować program koncertu. A więz przede wszystkim, zapomnianego przez naszych dyrygentów wspaniałego mistrza z końca XVII wieku, Stan. Sylwestra Szarzyńskiego: Concerto ...Pariendo non gravaris“ w układzie chórowym: „.Dziś narodziło nam się Dzieciẹ" (chór z Mesjasza Haendla); natchnione Szeli- 
gowskiego „Angeli słodko śpiewali“ (tekst z XV w. o Wniebowzięciu N. M. P.), Kantata I. O. Mańskiego „Ze świtaniem rannej zorzy“, oraz triumfalny chór wstępny z Magnificat J. Seb! Bacha, jako finał:

Trzeba przyznać, koncert był trudny, może nawet bardzo trudny i dość wyczerpujący, dał jednak w rezultacie taką sumę przeżyć estetycznych i religijnych, że słuchacze nie zapomną go może przez wiele, wiele lat. Dobre chóry seminaryjne i zakonne mogły by ten program z pewnymi może zmianami powtórzyć. A chóry średnie i słabsze, czy nie byłyby również $\mathrm{W}$ stanie urządzić koncert w ramach swoich możliwości ? Ależ tak! Trzeba tylko sprawe rozważyć od strony praktycznej.

Podawać tu jakieś gotowe schematy repertuarowe, czy programy byłoby rzeczą naiwną i mijałoby się z celem. Muszą być wzięte pod uwage tak warunki lokalne, jak i skład chóru, obecność solistów, instrumentalistów itd., czyli że rozstrzygającym będzie to, co na miejscu zadecydują dyrygent-organista wspólnie z rektorem kościoła, który zresztą nie tylko jak najżyczliwiej odniesie się do tej apostolskiej imprezy, ale sam zrobi wszystko, by ona doszla do skutku.

Biorąc pod uwagę stronę praktyczną urządzenia koncertu pieśni maryjnej, liczyć się trzeba z tym, czy zaktualizowanie omawianych projektów przez chóry małomiasteczkowe i wiejskie nie natrafi na trudności nie do przezwyciężenia. Przede wszystkim, jeśli poprzednio wyłożone myśli miałyby przestraszyć lub znieshęcić kierowników chórów do podjęcia tego rodzaju imprez, to gwoli uspokojenia, należy wyjaśnić, że poziom słuchaczy środków artystycznych, jak przy elemencie miejskim. Doświadczenie uczy, że dużo lepszy efekt osiągnie się. przez ciekawe wykonanie pieśni dwugłosowej, a nawet unisonowej, śpiewanej przez chór zbiorowy z rzetelnym towarzyszeniem organowym (tak rzadko się go teraz słyszy, bo organiści lubią improwizować) niż bezduszne wykonanie 4-głosowego utworu, polifonicznego bez wyrazu. Chórom takim mogą oddać usługę pieśni maryjne 2- i 4-głosowe ks. Chlondowskiego, ks. Krawczyka i inne. Księgadnia Wyd. św. Jacka w Katowicach przygotowuje: „15 nowych pieśni maryjnych“ (w różnych układach).

Dla chórów średnich można by polecić poza Wydawnictwami Barwickiego, Maklakiewicza: „Wypłynęła“, „Kwiecie cudny“ i inne Gruberskiego: „Pokłon Przeczystej Dziewicy“ (opuścić fugato „Grom, błyskawica“, gdyż robi wrażenie groteski. W szczególny sposób jednak trzeba wyróżnić tu wspaniałe kompozycje Stan. Sylw. Szarzyńskiego wydane przez P. W. IM. Wystarczy przypomnieć, że z okazji Festiwalu Muzyki w Salzburgu (w okresie międzywojennym), Niemcy porównywali go z samym J. Seb. Bachem, podkreślając, że przewyższa go słowiańską melodyjnością.

W związku z tym uprzytomnić sobie trzeba caly szereg drobnych szczegółów, ale bardzo istotnych, od których zależy osiągnięcie waściwego celu koncertu. I tak: 1) To nie ma być popis chóru, bo chór w czasie tego koncertu ma zadanie znacznie większe, jak popisywanje 
się. 2) Koncert składa się z dwóch części z kilkuminutową przerwą. Każda część z osobna stanowi odrębną i zwartą całość, o wyraźnie zarysowanej linii architektonicznej. 3) Srodkiem do osiągnięcia tego celu jest słowo wiążące: oszczędne i nastrojowe. Czyta się je z ambony, a nie improwizuje. 4) W wykonaniu utworów należy opuszczać repetycje, tam gdzie są niekonieczne, celem uniknięcia znużenia u słuchacza. Przy bardzo krótkich pieśniach można i należy śpiewać 2-gą zwrotkę. 5) Wszelkie rozproszenie przekreśla cel koncertu. Dlatego należy zrobić wszystko, aby ono nie miało miejsca w czasie koncertu $z$ jakiejkolwiekbądź strony. Np. trzeba unikać przejaskrawienia przez solistów partii dramatycznych. Przerw między słowem wiążącym a śpiewem, czy muzyką nie powinno być wcale. 6) Treść słowa wiążącego jak również nastrój wykonywanych utworów winny.w miarę trwania koncertu wzmagać się, ogarniając coraz silniej swoim działaniem duszę słuchacza. 7) Jedyny oddech dopuszczalny i korzystny, to odśpiewanie kilku zwrotek przez wszystkich zebranych jakiej odpowiedniej, ogólnie znanej, pieśni religijnej. Wyjdzie to jeszcze lepiej, jeśli chór podejmie repetycję refrenu na głosy, lub naodwrót lud sam śpiewa refren pieśni, która przedtem chór podał w pięknej, charakterystycznej szacie harmonicznej. 8) Jeżeli tekst pieśni jest w języku łacińskim, należy go podać w brzmieniu polskim bezpośrednio przed wykonaniem utworu. 9) W doborze utworów muzycznych na pierwszym miejscu należy stawiać takie, które mogą przemówić przez swą wewnętrzną dynamikę emocjonalną. Gdzie jej brak, tam sam dyrygent musi utwór uczynić interesującym przez: skontrastowanie dynamiczne poszczególnych części lub okresów (piana i forte), zmiany tempa, synkopy, wzmacnianie wzbierające miarowo aż do wybrzmienia w triumfalnym fortissimo ostatniego członu. Frazom tematycznym, a nawet samym imitacjom wstępnym należy dać logiczną, ale stale utrzymaną formę ,która pozwoli słuchaczowi odróżnić je cd razu od elementów czysto harmonicznych. Nie ilość więc, lecz jakość utworów odgrywa tu rolę decydującą. Nieraz nawet tylko na fragmencie dłuższego utworu wypadnie poprzestać.

Te wszystkie szczegóły, wspomniane dość pobieżnie, mają zwrócić uwagę dyrygenta i wykonawców na konieczność użycia chwytów pokrewnych sztuce reżyserskiej i dekoratorskiej, by dotrzeć do ukrytych i zazdrośnie strzeżonych drzwi ludzkiego serca, prowadzących w głąb. Otwierają się one pod tchnieniem czarownej pieśni, budząc najserdeczniejsze tęsknoty serca ludzkiego za Dobrem, Prawdą i Pięknem.

Nie każda jednak dusza równie łatwo reaguje na bodźce muzyczne. Jak w organie Cortiego mogą istnieć struny zanikłe (zamarłe) wskutek nieużywania ich, tak też są uśpione struny i w duszach człowieczych. Latami całymi niedopuszczane do głosu, odrętwiały i trzeba dopiero wstrząsu, żeby odpowiedziały rezonansem i obudziły się do życia łaski. Zadanie chóru i muzyki religijnej, jak stąd widać, nie jest łatwe i proste. Idzie tu przecież o wywołanie najgłębszych reakcji psyəhicznych 
przez zadziałanie bodźców zewnętrznych $\mathrm{w}$ formie możliwie jak najbardziej doskonałej.

Koncert powiniẹn zakończyć się krótkim błogosławieństwem ze śpiewem, możliwie krótkim, żeby nie zatrzeć wrażeń z koncertu.

Ks. I. O. MAŃSKI, Sal. D. B.

\section{Wyjaśnienie w sprawie „Mszału“ Benedyktyńskiego}

W pewnej części nakładu wydanego ostatnio w Belgii 3-go wydania „Mszału rzymskiego“ O. Lefebł́re, w opracowaniu Benedyktynów z Tyńca, wydrukowano teksty nowej liturgii Wielkiego Tygodnia w przekładzie dokonanym przez grupę świeckich tłumaczy w Belgii, bez korekty w kraju. Dlatego opactwo w Tyńcu nie odpowiada za usterki językowe i rzeczowe w tych tekstach. W dalszej części nakładu błędy te usunięto.

\section{OGEOSZENIE}

\section{Ceremonial obrzędów Wielkiego Tygodnia}

w języku polskim, zawierający teksty komentarza oraz szczególowe objaśnienia dla Celebransa, ministrantów organisty i zakrystiana wysyłają za zaliczeniem pocztowym.

OO. BENEDYKTYNI

Tyniec - Opactwo, p. Skawina 